\title{
Realistic Mathematics Education (RME) untuk Meningkatkan Kemampuan Pemecahan Masalah Matematis Siswa di Indonesia
}

\author{
I Wayan Widana \\ Program Studi Pendidikan Matematika, Universitas PGRI Mahadewa Indonesia \\ i.wayan.widana.bali@gmail.com
}

\begin{abstract}
Abstrak
Kemampuan pemecahan masalah dalam kehidupan sehari-hari merupakan kompetensi utama yang harus dimiliki oleh peserta didik pada abad ke-21. RME mampu menjembatani konsep abstrak matematika yang diperoleh di dalam kelas dengan dunia nyata. Penelitian ini merupakan penelitian meta-analisis bertujuan untuk menganalisis pengaruh model pembelajaran $R M E$ terhadap kemampuan pemecahan masalah. Data diperoleh dari penelusuran artikel ilmiah yang telah dipublikasikan pada jurnal terakreditasi Science and Technology Index (SINTA) 2, 3, dan 4 serta prosiding nasional dalam rentang tahun 2016-2021 dan merupakan penelitian eksperimen dengan desain non-equivalen control grup pre-test and post-test design. Sampel penelitian yang sesuai kriteria ekslusi dan inklusi sebanyak 7 artikel. Data dianalisis menggunakan aplikasi $J A S P V-0.11$. Hasil uji heterogenitas dengan nilai $\mathrm{Q}=10,277$ dan $\mathrm{p}=0,113>0,05$. Model penggabungan effect size yang digunakan adalah fixed effect model. Hasil penelitian menunjukkan bahwa rerata effect size sebesar 0,42 dalam kategori efek sedang dan hasil uji Funnel Plot dan Egger's Test dengan nilai z $=0,075$ dan $\mathrm{p}=0,940$ $>0,05$ menunjukkan tidak terdapat bias publikasi. Kesimpulan, model pembelajaran $R M E$ berpengaruh terhadap kemampuan pemecahan masalah matematika peserta didik dengan pengaruh sedang. Hasil penelitian ini berkontribusi untuk memperkuat temuantemuan penelitian sebelumnya.
\end{abstract}

Kata kunci: meta-analisis, pemecahan masalah, Realistic Mathematics Education

\begin{abstract}
Problem-solving ability in the real world is the main competency that students must possess in the 21 st century. RME can bridge abstract mathematical concepts obtained in the classroom with the real world. This research is a meta-analytic study aimed at analyzing the effect of the RME learning model on problem-solving abilities. The data was obtained from a search of scientific articles that have been published in Science and Technology Index (SINTA) 2, 3, and 4 accredited journals and national proceedings in the period 2016-2021 and is an experimental study with a non-equivalent pre-test and post-test control group design. The research samples that matched the exclusion and inclusion criteria were seven units. The data were analyzed using the JASP V-0.11 application. The results of the heterogeneity test with a value of $Q=10.277$ and $\mathrm{p}=0.113>0.05$. The combined effect size model used is the fixed effect model. The results showed that the average effect size was 0.42 in the medium effect category. The Funnel Plot and Egger's Test tests with a value of $z=0.075$ and $p=0.940>0.05$ indicated no publication bias. In conclusion, the RME learning model affects students' mathematical problem-solving abilities with moderate influence. The results of this study contribute to strengthening the findings of previous studies.
\end{abstract}

Keywords: meta-analysis, problem-solving, Realistic Mathematics Education

Received: June 1, 2021 / Accepted: July 9, 2021 / Published Online: July 16, 2021 


\section{Pendahuluan}

Lady et al. (2018) mengemukakan bahwa Realistic Mathematics Education (RME) merupakan model pembelajaran matematika yang berbasis pada realita dan lingkungan di sekitar peserta didik. Guru berupaya menyajikan pembelajaran dengan cara memanfaatkan contoh-contoh nyata yang dapat dilihat atau dialami oleh peserta didik. Lauren et al. (2018) dan Fauzan et al. (2017) mengemukakan bahwa prinsip-prinsip pembelajaran $R M E$ adalah sebagai berikut: (1) berbasis aktivitas, guru harus mampu mendorong peserta didik agar aktif secara fisik dan mental; (2) berbasis realita, pelajaran dimulai dengan mengangkat permasalahan riil di sekitar lingkungan belajar peserta didik; (3) penyelesaian masalah secara berjenjang, peserta didik diarahkan untuk melakukan tahapan-tahapan tertentu untuk menyelesaikan masalah; (4) keterhubungan, menunjukkan kaitan antara konsep matematika satu dengan yang lainnya, tidak terpisah-pisah; dan (5) interaksi sosial, kegiatan pembelajaran matematika agar mampu menciptakan hubungan sosial antara guru dan peserta didik sehingga pembelajaran berlangsung interaktif, aktif, dan menyenangkan.

Lebih lanjut Papadakis (2021) menyatakan bahwa model pembelajaran $R M E$ berkaitan dengan konsep-konsep matematika, kemampuan berpikir kritis, berpikir kreatif, dan pemecahan masalah. Warsito et al. (2018) menyatakan bahwa model pembelajaran $R M E$ memberikan kesempatan yang seluas-luasnya bagi peserta didik untuk membangun pengetahuan sendiri melalui proses pemecahan permasalahan yang diberikan. Selanjutnya, Ndiung et al. (2021) menyatakan bahwa RME memiliki kelebihan dan kekurangan. Adapun kelebihan model $R M E$ antara lain: (1) peserta didik lebih aktif dan mandiri untuk menemukan konsep dan teori-teori dalam pembelajaran, sehingga mereka mampu menghubungkan konsep tersebut dengan kehidupan sehari-hari; (2) $R M E$ juga mampu meningkatkan kesungguhan dalam pembelajaran karena pembelajaran berbasis aktivitas, sehingga semua peserta didik terlibat aktif dalam pembelajaran. Di sisi lain, terdapat beberapa kekurangan $R M E$ yaitu: (1) guru enggan melakukan persiapan mengajar dengan lebih kreatif misalnya mencari contohcontoh nyata tentang konsep-konsep yang akan diajarkan; (2) guru kesulitan untuk memperkaya media pembelajaran berbasis benda nyata yang sesuai dengan konsep yang akan dipelajari.

Setiawan et al. (2020) menyatakan bahwa kemampuan pemecahan masalah dapat dilatih secara formal di sekolah melalui pembelajaran dan penilaian. Guru-guru hendaknya mampu menciptakan iklim pembelajaran yang mampu memfasilitasi pengembangan kemampuan pemecahan masalah peserta didik. Malik et al. (2019) menyatakan bahwa berpikir kreatif merupakan salah satu ciri keterampilan yang harus dimiliki peserta didik untuk mendukung kemampuan pemecahan masalah. Dengan kreativitas yang tinggi, peserta didik memiliki 
kemampuan pemecahan masalah yang lebih baik. Mereka memiliki berbagai cara untuk menyelesaikan masalah baik melalui kegiatan modifikasi atau menciptakan cara-cara baru yang belum pernah dilakukan sebelumnya.

Menurut Suparman et al. (2021) permasalahan yang disajikan dalam mata pelajaran matematika ada 2 yaitu: (1) masalah yang bersifat rutin, umumnya masalah-masalah yang digunakan untuk menguji penerapan konsep, rumus, atau teorema matematika tertentu. Untuk menyelesaikan masalah rutin, siswa hanya perlu memahami konsep-konsep matematika dan bagaimana menggunakannya untuk menyelesaikan masalah tersebut; (2) masalah tidak rutin yaitu masalah baru bagi peserta didik, artinya masalah itu memiliki karakteristik yang berbeda dengan masalah-masalah yang sering dijumpai peserta didik sebelumnya. Untuk menyelesaikan masalah-masalah yang tidak rutin, memerlukan inovasi dan kreativitas yang tinggi (Astriani et al., 2021). Peserta didik tidak cukup dengan cara meniru langkah-langkah penyelesaian masalah-masalah seperti yang pernah dijumpainya. Peserta didik harus melakukan langkahlangkah tambahan tertentu misalnya memodifikasi penyelesaian masalah yang pernah dilakukan atau membuat tahapan-tahapan penyelesaian masalah tidak rutin itu ke dalam beberapa penyelesaian masalah yang telah dikenalnya. Mungkin pula dilakukan dengan mentransfer masalah tidak rutin itu pada masalah yang pernah dikenalnya (Hobri et al., 2020).

Permasalahan-permasalahan yang tidak rutin dapat diselesaikan dengan keterampilan berpikir tingkat tinggi (higher-order thinking skills/HOTS). Widana et al. (2020) menyatakan bahwa level kognitif yang termasuk dalam ranah keterampilan berpikir tingkat tinggi meliputi kemampuan menganalisis, mengevaluasi, dan mengkreasi. Indrawanti et al. (2019) mengemukakan bahwa tahapan-tahapan pemecahan masalah yang tidak rutin dapat dirumuskan sebagai berikut: (a) mengidentifikasi dan memahami karakteristik masalah, (b) mengelompokkan/mengorganisasikan data relevan yang diketahui, (c) membuat model rumusan masalah dalam bentuk simbol-simbol matematis; (d) memilih pendekatan atau strategi yang sesuai untuk memecahkan masalah, (e) mengkreasi atau mengembangkan pendekatan pemecahan masalah, dan (f) menyimpulkan, menginterpretasikan atau menafsirkan penyelesaian model matematika yang diperoleh untuk memecahkan masalah.

Kurniawati et al. (2020) menyatakan bahwa pemecahan masalah (problem-solving) dapat dilakukan dengan menggunakan penalaran terhadap sifat-sifat dalam konsep dasar matematika dan melakukan manipulasi bentuk-bentuk matematika misalnya dengan cara penyederhanaan, mengidentifikasi, dan melakukan analisis terhadap aspek-aspek yang ada dalam pemecahan masalah baik pada ruang lingkup matematika maupun dalam kehidupan sehari-hari. Kemampuan pemecahan masalah meliputi kemampuan mengidentifikasi dan memahami 
masalah, menyusun model matematika yang sesuai masalah, menyelesaikan model matematika yang telah disusun sebelumnya serta menafsirkan solusi yang diperoleh sesuai dengan tujuan memecahkan masalah yang diberikan (Rahman, 2019).

Penelitian ini difokuskan pada kajian terhadap artikel-artikel yang telah dipublikasikan melalui berbagai jurnal nasional terakreditasi SINTA 2, 3, dan 4 serta prosiding nasional tentang efektivitas model pembelajaran $R M E$ untuk meningkatkan kemampuan pemecahan masalah. Jumlah sampel yang digunakan oleh para peneliti sebelumnya relatif kecil, sehingga ada kemungkinan kesimpulan yang diperoleh mengandung unsur bias. Oleh karena itu perlu dilakukan penelitian meta-analisis untuk memperoleh kesimpulan yang lebih akurat dan akuntabel. Tujuan penelitian ini adalah untuk menganalisis pengaruh model pembelajaran $R M E$ terhadap kemampuan pemecahan masalah menggunakan data hasil penelitian terdahulu dengan jumlah sampel yang lebih besar, sehingga dapat diminimalkan adanya unsur bias.

\section{Metode}

Penelitian ini merupakan penelitian meta-analisis menggunakan metode Preferred Reporting Items for Systematic Reviews and Meta-analyses (PRISMA). Pemilihan metode PRISMA didasarkan pertimbangan yaitu memiliki tahapan-tahapan yang sangat sistematis dan prosedur akurat sesuai kaidah ilmiah penelitian (Parwata, 2021). Langkah-langkah metode PRISMA adalah: 1) background and purpose, 2) research question, 3) searching for the literature, 4) selection criteria, 5) practical screen, 6) quality checklist and procedures, 6) data extraction strategy, 7) data synthesis strategy (Retnawati et al., 2018). Secara operasional, langkah-langkah pelaksanaan metode PRISMA diuraikan sebagai berikut.

Pertanyaan penelitian dirumuskan berdasarkan perbandingan pre-post (pre-post contrast), yang bertujuan untuk memeriksa perubahan variabel kemampuan pemecahan masalah sebelum dan sesudah diberikan treatment berupa model pembelajaran RME. Populasi penelitian adalah penelitian-penelitian sejenis dan relevan dengan judul pengaruh model pembelajaran $R M E$ terhadap kemampuan pemecahan masalah. Pencarian data penelitian menggunakan database Google Scholar (https://scholar.google.com/), SINTA (https://sinta.ristekbrin.go.id/journals), dan Directory of Open Access Journal (DOAJ) (https://doaj.org/). Sampel penelitian dipilih dari populasi menggunakan kriteria-kriteria sebagai berikut: (1) menetapkan kata kunci yaitu RME, Realistic Mathematics Education, problem solving, dan kemampuan pemecahan masalah; (2) country: Indonesia; (3) jenis publikasi yaitu artikel ilmiah pada jurnal nasional terakreditasi SINTA 2, 3, dan 4 serta prosiding nasional; (4) tahun terbit 2016-2021; dan (5) jenis penelitian kuasi eksperimen desain 
nonequivalent pre-test and post-test control group design. Alur penelusuran artikel dan prosiding dapat digambarkan sebagai berikut.

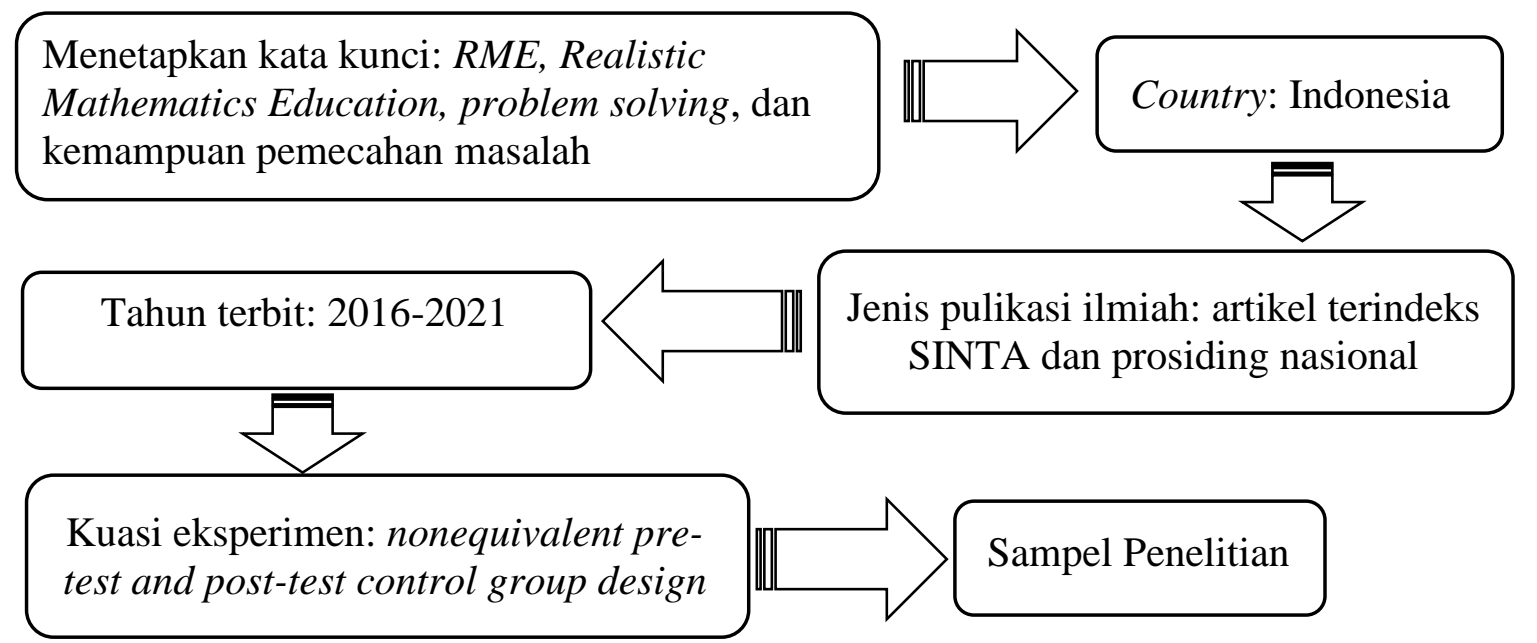

Gambar 1. Alur penelusuran artikel ilmiah dan prosiding

Penelitian ini dilakukan sejak bulan Maret sampai dengan bulan Juni 2021 di Denpasar. Data hasil penelitian diolah dan dianalisis menggunakan bantuan software JASP V-0.11 untuk menghitung nilai effect size artikel yang menjadi sampel penelitian (Goss-Samspson, 2019). Selanjutnya, untuk menentukan model penggabungan effect size dilakukan dengan uji heterogenitas. Bila nilai $\mathrm{p}>0,05$ maka model penggabungan effect size menggunakan model fixed effect, sedangkan bila nilai $\mathrm{p}<0,05$ maka model penggabungan effect size menggunakan random effect model (Renawati et al., 2018).

Glass et al. (1981) mengklasifikasikan effect size menjadi 5 kategori yang menunjukkan kuat-lemahnya pengaruh model pembelajaran $R M E$ terhadap kemampuan pemecahan masalah, seperti pada Tabel 1 berikut.

Tabel 1. Interval Effect Size (ES)

\begin{tabular}{lll}
\hline No. & \multicolumn{1}{c}{ Interval } & \multicolumn{1}{c}{ Interpretasi } \\
\hline 1. & $E S \leq 0,15$ & Pengaruh diabaikan \\
2. & $0,15<E S \leq 0,40$ & Pengaruh rendah \\
3. & $0,40<E S \leq 0,75$ & Pengaruh sedang \\
4. & $0,75<E S \leq 1,10$ & Pengaruh tinggi \\
5. & $1,10<E S \leq 1,45$ & Pengaruh sangat tinggi \\
\hline
\end{tabular}

\section{Hasil Penelitian}

Sesuai dengan langkah-langkah penelitian yang telah ditetapkan, terlebih dahulu melakukan penjaringan artikel ilmiah di jurnal nasional terakreditasi SINTA 2, 3, dan 4 serta prosiding nasional dengan menentukan kata kunci yaitu RME, Realistic Mathematics Education, problem solving, dan kemampuan pemecahan masalah. Pencarian data penelitian menggunakan database Google Scholar, SINTA, dan DOAJ. Langkah selanjutnya adalah 
melakukan seleksi berturut-turut berdasarkan country penerbit, jenis publikasi ilmiah, tahun terbit, dan jenis penelitian. Hasil penelusuran artikel selengkapnya disajikan pada Tabel 2 sebagai berikut.

Tabel 2. Data Hasil Penelusuran Artikel

\begin{tabular}{|c|c|c|}
\hline No. & Tahapan/Kriteria & Jumlah \\
\hline 1. & Kata kunci: $R M E$ dan problem solving (kemampuan pemecahan masalah) & 2.311 \\
\hline 2. & Country: Indonesia & 524 \\
\hline 3. & Jenis publikasi: artikel ilmiah terakreditasi SINTA dan prosiding nasional & 98 \\
\hline 4. & Tahun terbit 2016-2021 & 46 \\
\hline 5. & $\begin{array}{l}\text { Jenis penelitian kuasi eksperimen desain nonequivalent pre-tes and post- } \\
\text { tes control group design }\end{array}$ & 14 \\
\hline 6. & Sampel penelitian & 7 \\
\hline
\end{tabular}

Tabel 2 di atas menunjukkan data hasil penelusuran sesuai dengan tahapan penelusuran dan kriteria yang telah ditetapkan. Jumlah sampel yang memenuhi syarat inklusi dan ekslusi sebanyak 7 buah yang terdiri dari 5 artikel di jurnal terakreditasi SINTA 2, 3, dan 4 serta 2 artikel di prosiding nasional. Data-data sampel yang terpilih disajikan pada tabel 3 berikut.

Tabel 3. Data Sampel Penelitian

\begin{tabular}{|c|c|c|c|}
\hline No. & Judul Artikel & Nama Penulis & Nama Jurnal/Prosiding \\
\hline 1. & $\begin{array}{l}\text { Using realistic mathematics education } \\
\text { in mathematical problem-solving } \\
\text { ability based on students, } \\
\text { mathematical initial ability }\end{array}$ & $\begin{array}{l}\text { 1. Ima Nurfadilah } \\
\text { 2. Hepsi } \\
\text { 3. Abdul Fatah }\end{array}$ & $\begin{array}{l}\text { Prima: Jurnal Pendidikan } \\
\text { Matematika } \\
\text { Vol. } 5 \text { No. 1, (2021) } \\
\text { Terakreditasi SINTA } 3\end{array}$ \\
\hline 2. & $\begin{array}{l}\text { Pemanfaatan media audio visual } \\
\text { berbasis realistic mathematics } \\
\text { education }(R M E) \text { terhadap } \\
\text { kemampuan pemecahan masalah } \\
\text { siswa MTs Raudhatun Najah Langsa }\end{array}$ & Saprizal & $\begin{array}{l}\text { Jurnal Ilmiah Pendidikan } \\
\text { Matematika AL- } \\
\text { QALASADI, Vol. } 2 \text { No. 2, } \\
\text { (2018) } \\
\text { Terakreditasi SINTA } 4\end{array}$ \\
\hline 3. & $\begin{array}{l}\text { Meningkatkan kemampuan } \\
\text { pemecahan masalah matematika dan } \\
\text { self-efficacy siswa MTs melalui } \\
\text { pendekatan pendidikan matematika } \\
\text { realistik }\end{array}$ & Susanti & $\begin{array}{l}\text { Suska: Journal of } \\
\text { Mathematics Education } \\
\text { Vol 3, No 2, (2017) } \\
\text { Terakreditasi SINTA } 4\end{array}$ \\
\hline 4. & $\begin{array}{l}\text { Pengaruh pendekatan } R M E \text { terhadap } \\
\text { kemampuan pemecahan masalah } \\
\text { siswa pada materi operasi hitung } \\
\text { campuran di kelas IV SD IT Adzkia I } \\
\text { Padang }\end{array}$ & Asrina Mulyati & $\begin{array}{l}\text { Jurnal Didaktik Matematika } \\
\text { Vol 4. No. 1, (2017) } \\
\text { Terakreditasi SINTA } 2\end{array}$ \\
\hline 5. & $\begin{array}{l}\text { Penerapan pembelajaran matematika } \\
\text { realistik untuk meningkatkan } \\
\text { kemampuan pemecahan masalah } \\
\text { matematika siswa SMP Negeri } 8 \\
\text { Lhokseumawe }\end{array}$ & Lisa & $\begin{array}{l}\text { Prosding Seminar Nasional } \\
\text { Integrasi Matematika dan } \\
\text { Nilai Islami, Vol. 3, No. 1, } \\
\text { (2019) }\end{array}$ \\
\hline 6. & $\begin{array}{l}\text { Penerapan pendekatan realistic } \\
\text { mathematics education }(R M E) \\
\text { terhadap kemampuan pemecahan } \\
\text { masalah matematika siswa SMA }\end{array}$ & $\begin{array}{ll}\text { 1. } & \text { Vera Nopianti } \\
& \text { Siregar } \\
\text { 2. } & \text { Ramlah } \\
\text { 3. } & \text { Kiki Nia Sania } \\
& \text { Effendi } \\
\end{array}$ & $\begin{array}{l}\text { Sesiomadika: Prosiding } \\
\text { Seminar Nasional } \\
\text { Matematika dan Pendidikan } \\
\text { Matematika, (2018) }\end{array}$ \\
\hline
\end{tabular}




\begin{tabular}{rlll}
\hline No. & Judul Artikel & Nama Penulis & Nama Jurnal/Prosiding \\
\hline 7. & Penerapan pendekatan matematika & Sarbiyono & JRPM (Jurnal Review \\
& $\begin{array}{l}\text { realistik terhadap kemampuan } \\
\text { pemecahan masalah matematika siswa }\end{array}$ & & Pembelajaran Matematika), \\
& & Vol. 1, No. 2, (2016) \\
& & Terakreditasi SINTA 3 \\
\hline
\end{tabular}

Dari masing-masing sampel penelitian di atas dicatat data-data statistik meliputi jumlah sampel masing-masing kelompok eksperimen dan kontrol, nilai rerata (mean), dan standar deviasi (SD). Data selengkapnya disajikan pada tabel 4 berikut.

Tabel 4. Data Statistik Sampel Penelitian

\begin{tabular}{crrrrrr}
\hline $\begin{array}{l}\text { Sampel } \\
\text { ke: }\end{array}$ & \multicolumn{3}{c}{ Kelompok Eksperimen } & & \multicolumn{3}{c}{ Kelompok Kontrol } & \\
\cline { 2 - 7 } & $\mathbf{N}$ & Mean & SD & N & Mean & SD \\
\hline 1 & 14 & 51,57 & 14,840 & 10 & 39,800 & 17,970 \\
\hline 2 & 31 & 79,48 & 12,190 & 31 & 74,910 & 11,390 \\
\hline 3 & 33 & 80,01 & 6,942 & 33 & 79,200 & 9,867 \\
\hline 4 & 40 & 73,92 & 16,000 & 41 & 64,820 & 15,000 \\
\hline 5 & 33 & 32,00 & 5,357 & 32 & 24,327 & 4,829 \\
\hline 6 & 36 & 83,31 & 6,794 & 36 & 77,420 & 6,267 \\
\hline 7 & 40 & 10,15 & 2,547 & 40 & 8,850 & 2,587 \\
\hline
\end{tabular}

Berdasarkan data statistik pada tabel 4 di atas, selanjutnya dilakukan uji heterogenitas untuk menentukan model penggabungan effect size. Hasil analisis disajikan pada tabel 5 berikut.

Tabel 5. Hasil Uji Heterogenitas

\begin{tabular}{llcc}
\hline & Q & df & p \\
\hline Omnibus test of Model Coefficien & 10,911 & 1 &, 001 \\
Test of Residual Heterogenitas & 10,277 & 6 & 0,113 \\
\hline
\end{tabular}

Pada tabel 5 di atas terlihat nilai Test of Residual Heterogenitas dengan nilai Q = 10,277 dan $p=0,113>0,05$. Hal itu berarti bahwa heterogenitas data tidak signifikan atau data bersifat homogen. Dengan demikian maka model penggabungan effect size yang digunakan adalah fixed effect model.

Selanjutnya, besar effect size masing-masing artikel dan efek gabungan diperlihatkan oleh gambar 2 Forest Plot sebagai berikut. 


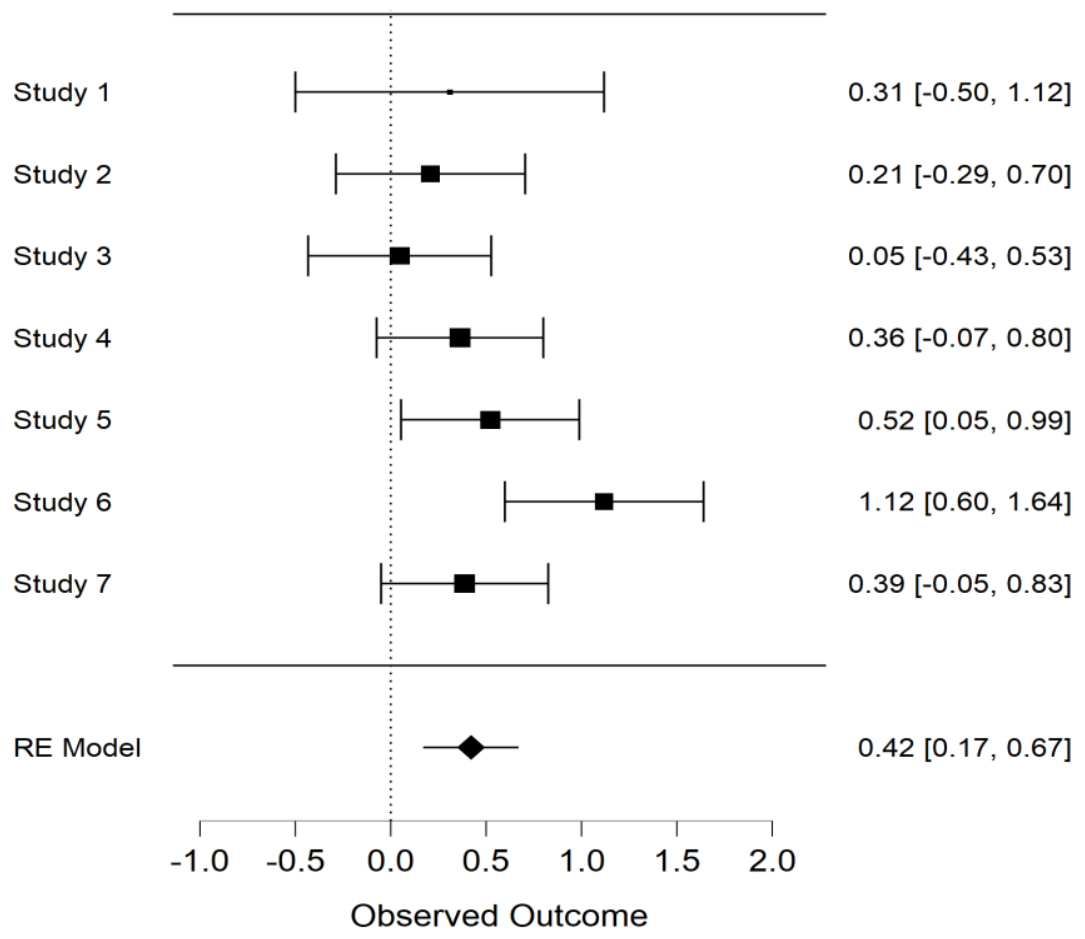

Gambar 2. Forest Plot

Gambar 2 di atas menyajikan rangkuman hasil meta analisis, pada bagian kiri menunjukkan terdapat 7 artikel yang dianalisis. Kotak hitam menunjukkan besarnya effect size masing-masing artikel. Semakin ke kanan posisi kotak hitam menunjukkan bahwa nilai effect size artikel semakin besar. Nilai effect size terlihat bervariasi dengan nilai terendah sebesar 0,05 pada artikel nomo 3. Sedangkan nilai effect size tertinggi terdapat pada artikel nomor 6 sebesar 1,12. Nilai mean effect size untuk semua artikel ditunjukkan oleh kotak berbentuk wajik (diamond) sebesar 0,42 dengan nilai batas bawah 0,17 dan batas atas 0,67 berada pada katagori efek sedang karena berada dalam interval 0,40 $<E S \leq 0,75$ (Glass et al., 1981). Dengan demikian dapat disimpulkan bahwa ada pengaruh model pembelajaran $R M E$ terhadap kemampuan pemecahan masalah dengan efek sedang.

Selanjutnya dilakukan uji Funnel Plot dan Egger's Test bertujuan untuk melakukan uji bias publikasi pada penelitian meta-analisis ini. Bias publikasi dapat dilihat dari bentuk Funnel Plot dengan ketentuan bahwa apabila gambar Funnel Plot berbentuk simetris dapat disimpulkan bahwa tidak terdapat bias publikasi. Sebaliknya, bila gambar Funnel Plot tidak berbentuk simetris berarti bahwa terdapat bias publikasi. Untuk meningkatkan presisi analisis bias publikasi menggunakan uji Funnel Plot, dilakukan dengan melakukan uji Egger's Test. Apabila nilai $\mathrm{p}>0,05$ berarti bahwa gambar Funnel Plot simetris dan sebaliknya bila nilai $\mathrm{p}<0,05$ berarti bahwa gambar 3 Funnel Plot tidak simetris. 


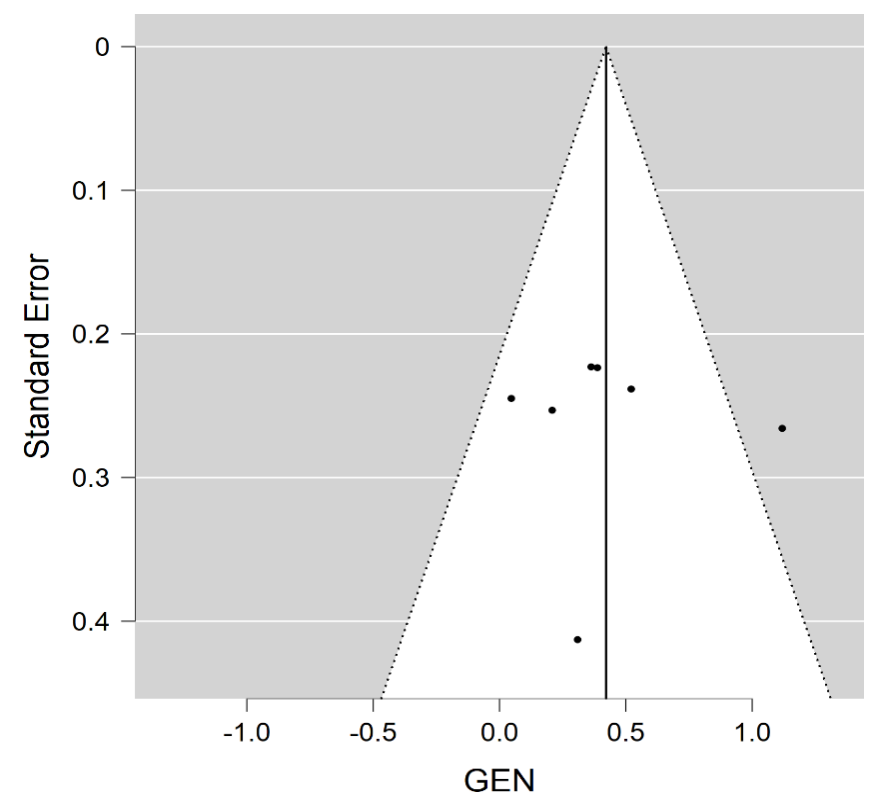

Gambar 3. Funnel Plot

Pada gambar 3 terlihat bahwa gambar Funnel Plot berbentuk simetris, dan titik-titik sampel masing-masing artikel dan prosiding berada pada area segitiga. Untuk meningkatkan akurasi hasil uji Funnel Plot di atas dilakukan Egger's Test sebagai berikut.

Tabel 6. Hasil Uji Egger's Test

\begin{tabular}{ccc}
\hline \multicolumn{2}{l}{ Regression test for Funnel plot asymmetry ("Egger's test") } \\
\hline zei & $\mathbf{p}$ \\
\hline sei & 0,075 & 0,940 \\
\hline
\end{tabular}

Pada tabel 6 uji Egger's Test di atas terlihat nilai p =0,940 > 0,05 berarti bahwa gambar Funnel Plot simetris. Dengan demikian dapat disimpulkan bahwa tidak terdapat bias publikasi dalam penelitian ini.

\section{Pembahasan}

Hasil penelitian meta-analisis menunjukkan ada pengaruh model pembelajaran $R M E$ terhadap kemampuan pemecahan masalah yang dibuktikan dengan nilai effect size sebesar 0,42 berada dalam kategori pengaruh sedang pada interval 0,40 < effect size $\leq 0,75$ (Glass et al., 1981) dan tidak terdapat unsur bias publikasi. Hasil penelitian meta-analisis pengaruh model pembelajaran $R M E$ terhadap kemampuan pemecahan masalah matematika peserta didik memperkuat temuan-temuan penelitian sebelumnya. Dengan demikian dapat dikatakan bahwa model pembelajaran $R M E$ dapat meningkatkan kemampuan pemecahan masalah peserta didik.

Penelitian yang dilakukan oleh Nurfadilah et al. (2021) pada Forest Plot menunjukkan effect size sebesar 0,31 dengan interval terlebar dibandingkan dengan penelitian lainnya [-0,5 - 
1,12]. Hal itu berarti bahwa pengaruh model pembelajaran $R M E$ terhadap kemampuan pemecahan masalah matematika dalam kategori rendah. Demikian pula penelitian yang dilakukan oleh Saprizal (2018) dengan nilai effect size sebesar 0,21 dengan interval [-0,29 0,70] dalam kategori pengaruh rendah. Penelitian Susanti (2017) dengan nilai effect size sebesar 0,05 dengan interval [-0,43 - 0,53] dalam kategori pengaruh diabaikan. Mulyati (2017) dengan nilai effect size sebesar 0,36 dengan interval $[-0,07-0,80]$ dalam kategori pengaruh rendah. Selanjutnya pada penelitian Lisa (2019) dengan nilai effect size sebesar 0,52 dengan interval [0,05 - 0,99] dalam kategori pengaruh sedang. Penelitian Nopianti et al. (2018) dengan nilai effect size sebesar 1,12 dengan interval [0,60 - 1,64] dalam kategori pengaruh sangat tinggi. Sarbiyono (2016) dengan nilai effect size sebesar 0,39 dengan interval [-0,05-0,83] dalam kategori pengaruh rendah.

Berdasarkan analisis nilai effect size dan interval pada masing-masing artikel di atas, terdapat sebuah artikel dengan pengaruh effect size pada kategori diabaikan (sangat rendah), 5 artikel dengan pengaruh effect size rendah, dan sebuah artikel dengan pengaruh effect size sangat tinggi. Adanya variasi pengaruh effect size pada masing-masing artikel di atas, diakibatkan oleh banyak faktor salah satunya adalah jumlah sampel yang kecil. Dengan menggabungkan effect size semua artikel, jumlah sampel menjadi lebih besar yaitu 227 orang untuk kelompok eksperimen dan 223 orang untuk kelompok kontrol. Setelah digabungkan, diperoleh nilai rerata effect size sebesar 0,42 dengan interval [0,17-0,67]. Hal ini menunjukkan bahwa jumlah sampel yang lebih besar dapat meningkatkan presisi hasil sebuah penelitian. Hasil meta-analisis data memperkuat temuan-temuan yang telah dihasilkan dalam penelitianpenelitian sebelumnya.

Keunggulan-keunggulan yang dimiliki oleh model pembelajaran $R M E$ seperti berbasis pada kondisi nyata, mampu memotivasi peserta didik belajar lebih giat karena mereka merasakan bahwa pembelajaran matematika berguna (Nurfadilah et al., 2021). Lebih lanjut Saprizal (2018) \& Mulyati (2017) dalam penelitiannya menyatakan bahwa konsep-konsep abstrak matematika lebih mudah dicerna oleh peserta didik berbasis media pembelajaran yang ada di lingkungan sekitar. Minat belajar matematika peserta menjadi meningkat untuk memanfaatkan teori-teori matematika untuk menyelesaikan masalah matematika yang diberikan guru. Bahkan peserta didik juga memperoleh dampak lainnya berupa peningkatan rasa percaya diri akan kemampuan matematika yang dimilikinya (Susanti, 2017). Rasa percaya diri peserta didik perlu dibangun oleh guru dalam pembelajaran. Hal-hal kecil yang dapat dicapai oleh peserta didik patut diberikan apresiasi. Melalui penerapan model pembelajaran 
$R M E$, secara tidak langsung peserta didik diajak mengenal dan memahami keunggulan lokal yang ada di daerahnya.

\section{Simpulan}

Nilai effect size dan interval masing-masing artikel sangat bervariasi. Salah satu penyebab munculnya variasi itu dipengaruhi oleh jumlah sampel penelitian relatif kecil. Setelah dilakukan penggabungan effect size menggunakan jumlah sampel yang jauh lebih besar, ternyata secara keseluruhan menghasilkan effect size dalam kategori pengaruh sedang. Hasil penelitian metaanalisis dapat memperkuat temuan-temuan dalam penelitian sebelumnya, sehingga dapat disimpulkan bahwa penerapan model pembelajaran $R M E$ dapat meningkatkan kemampuan pemecahan masalah matematika peserta didik dengan kategori pengaruh sedang dan tidak terdapat bias publikasi. Implikasi dari penelitian ini adalah model pembelajara RME dapat dijadikan alternatif oleh para guru matematika untuk meningkatkan kemampuan pemecahan masalah matematika peserta didik.

\section{Referensi}

Astriani, N., Surya, E., \& Syahputra, E. (2017). The effect of problem-based learning to students' mathematical problem-solving ability. IJARIIE, 3(2), 3441-3446.

Fauzan, A., Musdi, E., \& Yani, R. (2017). The influence of realistic mathematics education (RME) approach on students' mathematical representation ability. Advance in Social Science, Education and Humanities Research, 173, 9-12. https://doi.org/10.2991/icei17.2018.3.

Glass, Gene V., Graw. M. \& Smith, M.L. 1981. Meta-analysis in social research. Beverly Hills, CA: Sage Publications.

Goss-Samspson, M. A. (2019). Statistik analisis in JASP: A guide for students (2nd ed.). University of Greenwich.

Hobri, Ummah, I. K., Yuliati, N., \& Dafik. (2020). The effect of jumping task based on creative problem solving on students' problem-solving ability. International Journal of Instruction, 13(1), 387-406. https://doi.org/10.29333/iji.2020.13126a.

Indrawanti, D., Hobri, Hadi, A. F., Fauziah, E. W. (2019). Critical thinking ability in solving triangle problems based on lesson study for learning community (LSLC). IOP Conference Series: Earth and Environmental Science, 243(1), 012146. https://doi.org/10.1088/17551315/243/1/012146.

Kurniawati, R.P., Gunawan, I., Marlina, D. (2020). Mathematic literation abilities based on problem solving abilities in first class 4 of elementary school. Advances in Social Science, Education and Humanities Research, 487, 186-192. https://doi.org/10.2991/assehr.k.201112.033.

Lady, A., Utomo, B. T., \& Lovi, C. (2018). Improving mathematical ability and student learning outcomes through realistic mathematic education (RME) approach. International Journal of Engineering and Technology, 7(2), 55-57. https://doi.org/10.14419/ijet.v7i2.10.10954.

Lauren, T., Batlolona, F. A., Batlolona, J. R., Leasa, M. (2018). How does realistic mathematics education (RME) improve students' mathematics cognitive achievement? EURASIA 
Journal of Mathematics, Science and Technology Education, 14(2), 569-578. https://doi.org/10.12973/ejmste/76959.

Lisa. (2019). Penerapan pembelajaran matematika realistik untuk meningkatkan kemampuan pemecahan masalah matematika siswa SMP Negeri 8 Lhokseumawe. Prosiding Seminar Nasional Integrasi Matematika dan Nilai Islami, 3(1).

Malik, A., Nuraeni, Y., Samsudin, A., \& Sutarno, S. (2019). Creative thinking skills of students on harmonic vibration using model student facilitator and explaining (SFAE). Jurnal Ilmiah Pendidikan Fisika Al-Biruni, 8(1), 77-88. https://doi.org/10.24042/jipfalbiruni.v8i1.3056.

Mulyati, A. (2017). Pengaruh pendekatan RME terhadap kemampuan pemecahan masalah siswa pada materi operasi hitung campuran di kelas IV SD IT Adzkia I Padang. Jurnal Didaktik Matematika, 4(1), 90-97. https://doi.org/10.24815/jdm.v4i1.8484.

Ndiung, S., Sariyasa., Jehadus, E., \& Apsari, R. A. (2021). The effect of treffinger creative learning model with the use RME principles on creative thinking skill and mathematics learning outcome. International Journal of Instruction, 14(2), 873-888. https://doi.org/10.29333/iji.2021.14249a.

Nopianti, V. S., Ramlah, Effendi, K. N. S. (2018). Penerapan pendekatan realistik mathematics education (RME) terhadap kemampuan pemecahan masalah matematika siswa SMA. Prosiding Seminar Nasional Matematika dan Pendidikan Matematika (Sesiomadika), Universitas Singaperbangsa Karawang, hal. 245-257.

Nurfadilah, I., Hepsi, Fatah, A. (2021). Using realistic mathematics education in mathematical problem-solving ability based on students' mathematical initial ability. Prima: Jurnal Pendidikan Matematika, 5(1), 35-46. https://doi.org/10.31000/prima.v5i1.3166.

Papadakis, S., Kalogiannakis, M., \& Zaranis, N. (2021). Teaching mathematics with mobile devices and the Realistic Mathematical Education (RME) approach in kindergarten. Advances in Mobile Learning Educational Research, 1(1), 5-18. https://doi.org/10.25082/AMLER.2021.01.002.

Parwata, I. M. Y. (2021). Pengaruh metode problem based learning terhadap peningkatan hasil belajar pendidikan jasmani olahraga dan kesehatan: meta-analisis. Indonesian Journal of Educational Development, 2(1), 1-9.

Rahman, M. M. (2019). 21st century skill "problem solving": Defining the concept. Asian Journal of Interdisciplinary Research, 2(1), 64-74. https://doi.org/10.34256/ajir1917.

Retnawati, H., Apino, E., Kartianom, Djidu, H., Anasifa, R. D. (2018). Pengantar analisis meta. Yogyakarta: Parama Publishing.

Saprizal. (2018). Pemanfaatan media audio visual berbasis realistic mathematics education (RME) terhadap kemampuan pemecahan masalah siswa MTs Raudhatun Najah Langsa. Jurnal Ilmiah Pendidikan Matematika AL-QALASADI, 2(2), 41-49. https://doi.org/10.32505/qalasadi.v2i2.797.

Sarbiyono. (2016). Penerapan pendekatan matematika realistik terhadap kemampuan pemecahan masalah matematis siswa. Jurnal Review Pembelajaran Matematika, 1(2), 163-173. https://doi.org/10.15642/jrpm.2016.1.2.163-173.

Setiawan, B., Rachmadtullah, R., \& Iasha, V. (2020). Problem-solving method: The effectiveness of the pre-service elementary education teacher activeness in the concept of physics content. Jurnal Basicedu, 4(4), 1074-1083. https://doi.org/10.31004/basicedu.v4i4.484.

Suparman, Yohannes, Arifin, N. (2021). Enhancing mathematical problem-solving skills of indonesian junior high school students through problem-based learning: A systematic review and meta-analysis. Al-Jabar: Jurnal Pendidikan, 12(1), 1-16. 
Susanti. (2017). Meningkatkan kemampuan pemecahan masalah matematika dan self-efficay siswa MTs melalui pendekatan pendidikan matematika realistik. Suska: Journal of Mathematics Education, 3(2), 92-101. https://doi.org/10.24014/sjme.v3i2.4148.

Warsito, Darhim, \& Herman, T. (2018). Improving students' mathematical representational ability through RME-based progressive mathematization. Journal of Physics: Conference Series, 948(1), 012038. https://doi.org/10.1088/1742-6596/948/1/012038.

Widana, I. W., Sumandya, I. W., Sukendra, K., Sudiarsa, I. W. (2020). Analysis of conceptual understanding, digital literacy, motivation, divergent of thinking, and creativity on the teachers skills in preparing hots-based assessments. Jour of Adv Research in Dynamical \& Control Systems, 12(8), 459-466. https://doi.org/10.5373/JARDCS/V12I8/20202612.

Yuniati, B. Y., Armiati, \& Musdi, E. (2020). The influence of realistic mathematics education (RME) approach with the TANDUR on understanding the concepts and solving mathematical problems on grade 8 in SMP Negeri 1 Pantai Cermin. Journal of Physics: Conference Series, 1554(1), 012063. https://doi.org/10.1088/1742-6596/1554/1/012063. 